\title{
ANALISIS PENGARUH SIKLON TROPIS GILLIAN TERHADAP CURAH HUJAN DI WILAYAH RIAU DAN SEKITARNYA
}

\author{
Rini M.Sibarani
}

\begin{abstract}
Intisari
Siklon Tropis merupakan gangguan meteorologi yang disebabkan karena adanya pusat tekanan rendah di lautan. Syarat terbentuknya siklon tropis di daerah perairan adalah suhu muka laut (sst) cukup panas $\left(T>26^{\circ} \mathrm{C}\right)$. Salah satu Siklon Tropis yang terjadi di perairan Indinesia adalah Siklon Tropis Gillian. Siklon Tropis ini terjadi di Selatan Perairan Indonesia, yang berlangsung selama 5 hari dari tanggal 21 Maret -25 Maret 2014. Siklon Tropis Gillian ini mempengaruhi kondisi curah hujan di wilayah Indonesia bagian Utara, tepatnya di Pulau Sumatera Bagian Utara. Selama terjadinya Siklon Tropis Gillian mengakibatkan pengurangan Curah hujan di wilayah tersebut, terutama di daerah Provinsi Riau. Dari data yang diperoleh baik dari data Penakar POS METEOROLOGI maupun dari data Satelit TRMM Jaxa mulai tanggal 23 Maret - 27 Maret 2014, curah hujan yang tercatat di wilayah Riau dan sekitarnya mendekati $0 \mathrm{~mm}$. Hal ini membuktikan bahwa Siklon Tropis Gillian di selatan Perairan Jawa mempengaruhi curah hujan di Pulau Sumatera Bagian Utara (Riau).
\end{abstract}

\begin{abstract}
Abstrack
Tropical Cyclone is the meteorological disturbance due to the low pressure center in the ocean. Terms of tropical cyclone formation in the waters is the sea surface temperature (sst) is quite warm (T>260C). Tropical Cyclone Gillian is one of Tropical Cyclone that occurred in the waters of Indinesia. This tropical cyclones occur in the Southern waters of Indonesian, which lasted for 5 days from March 21 to March 25, 2014. Tropical Cyclone Gillian affects rainfall in the northern part of Indonesia, precisely in Northern Sumatra Island. During the Tropical Cyclone Gillian lead to a reduction in rainfall in the region, especially in the province of Riau. Rainfall data from the POS METEOROLOGY and TRMM Satellite Jaxa began on March 23 to March 27, 2014, was recorded in Riau area close to $0 \mathrm{~mm}$. This proves that the Tropical Cyclone Gillian in southern waters of Java affecting rainfall in Northern of Sumatera Island (Riau).
\end{abstract}

Kata Kunci : Siklon Tropis, Suhu Muka Laut, Curah hujan

\section{PENDAHULUAN}

Siklon Tropis merupakan gangguan meteorologi yang disebabkan karena adanya pusat tekanan rendah di lautan. Syarat terbentuknya siklon tropis di daerah perairan adalah suhu muka laut (sst) cukup panas ( $T$ > $26^{\circ} \mathrm{C}$ ) dan parameter Coriolis harus lebih besar dari nilai minimum yang terdapat pada lintang $5^{0}$ belahan bumi utara dan selatan.

Proses terbentuknya Siklon Tropis adalah sebagai berikut;

1. Terjadinya depresi tropis dimana kecepatan angin $v \leq 20$ knot dan terdapat satu isobar tertutup.

2. Terjadi badai tropis dimana kecepatan angin meningkat $(34<\mathrm{v}<64)$ knot dan terdapat beberapa isobar tertutup disekitar mata.

3. Terbentuk siklon tropis dimana kecepatan angin $v \geq 64$ knot.
Syarat yang diperlukan baik kondisi geografis maupun klimatologis dalam pembentukan siklon tropis adalah:

1. Suhu permukaan laut cukup panas, yaitu diatas $26^{\circ} \mathrm{C}$. Udara pada lapisan bawah lembab, udara ini menyebar naik dan lebih panas daripada atmosfer lingkungan sampai pada ketinggian $12 \mathrm{~km}$.

2. Parameter Coriolis harus lebih besar dari nilai minimum yang terdapat pada lintang sekitar $5^{0}$ belahan bumi utara dan selatan. Jika gaya Coriolis lemah maka siklon tidak terbentuk.

Siklon tropis merupakan badai dengan kekuatan yang besar yang disebabkan karena adanya pusat tekanan rendah di perairan. Radius rata-rata siklon tropis mencapai 150 hingga $200 \mathrm{~km}$. Siklon tropis terbentuk di atas lautan luas yang umumnya mempunyai suhu permukaan air laut hangat, lebih dari $26.5^{\circ} \mathrm{C}$. Angin kencang yang berputar di dekat pusatnya 
mempunyai kecepatan angin lebih dari 63 $\mathrm{km} / \mathrm{jam}$.

Secara teknis, siklon tropis didefinisikan sebagai sistem tekanan rendah non-frontal yang berskala sinoptik yang tumbuh di atas perairan hangat dengan wilayah perawanan konvektif dan kecepatan angin maksimum \pm 34 knot pada lebih dari setengah wilayah yang melingkari pusatnya, serta bertahan setidaknya enam jam (http://meteo.bmkg.go.id/siklon/learn/01/id).

Siklon tropis dapat menyebabkan kerusakan terutama yang diakibatkan oleh angin kencang, gelombang badai (strom surge), dan hujan lebat. Daerah pembentukan siklon tropis kurang lebih dua per tiganya terjadi di belahan bumi Utara.

Jumlah siklon tropis yang tumbuh dibelahan bumi utara rata-rata 57.3 kejadian dalam satu tahun dan dibelahan bumi selatan rata-rata 26.3 siklon tropis dalam setahun (berdasarkan data tahun 1968 - 1989).

Siklon tropis dapat terbentuk dengan persyaratan berikut ini:

1. Suhu permukaan laut sekurang-kurangnya $26.5 \mathrm{C}$ hingga ke kedalaman 60 meter

2. Kondisi atmosfer yang tidak stabil yang memungkinkan terbentuknya awan Cumulonimbus. Awan-awan ini, yang merupakan awan-awan guntur, dan merupakan penanda wilayah konvektif kuat, adalah penting dalam perkembangan siklon tropis.

3. Atmosfer yang relatif lembab di ketinggian sekitar $5 \mathrm{~km}$. Ketinggian ini merupakan atmosfer paras menengah, yang apabila dalam keadaan kering tidak dapat mendukung bagi perkembangan aktivitas badai guntur di dalam siklon.

4. Berada pada jarak setidaknya sekitar $500 \mathrm{~km}$ dari khatulistiwa. Meskipun memungkinkan, siklon jarang terbentuk di dekat ekuator.

5. Gangguan atmosfer di dekat permukaan bumi berupa angin yang berpusar yang disertai dengan pumpunan angin.

6. Perubahan kondisi angin terhadap ketinggian tidak terlalu besar. Perubahan kondisi angin yang besar akan mengacaukan proses perkembangan badai guntur.

Siklus hidup siklon tropis dapat dibagi menjadi empat tahapan, yaitu :

1. Tahap pembentukan

Ditandai dengan adanya gangguan atmoster. Jika dilihat dari citra satelit cuaca, gangguan ini ditandai dengan wilayah konvektif dengan awan-awan cumulonimbus. Pusat sirkulasi belum terbentuk, namun sudah tampak pada ujung sabuk perawanan yang membentuk spiral.

2. Tahap belum matang
Pada tahap ini wilayah konvektif kuat terbentuk lebih teratur membentuk sabuk perawanan melingkar (berbentuk spiral) atau membentuk wilayah yang bentuknya relatif bulat. Intensitasnya meningkat secara simultan ditandai dengan tekanan udara permukaan yang turun mencapai kurang dari $1000 \mathrm{mb}$ serta kecepatan angin maksimum yang meningkat hingga mencapai gale force wind (kecepatan angin $\geq 34$ knot atau 63 $\mathrm{km} / \mathrm{jam})$. Angin dengan kecepatan maksimum terkonsentrasi pada cincin yang mengelilingi pusat sirkulasi. Pusat sirkulasi terpantau jelas dan mulai tampak terbentuknya mata siklon.

3. Tahap matang

Pada tahap matang, bentuk siklon tropis cenderung stabil. Tekanan udara minimum di pusatnya dan angin maksimum di sekelilingnya yang tidak banyak mengalami fluktuasi berarti. Sirkulasi siklonik dan wilayah dengan gale force wind meluas, citra satelit cuaca menunjukkan kondisi perawanan teratur dan lebih simetris. Pada siklon tropis yang lebih kuat dapat jelas terlihat adanya mata siklon. Fenomena ini ditandai dengan wilayah bersuhu paling hangat di tengah-tengah sistem perawanan dengan angin permukaan yang tenang dan dikelilingi oleh dinding perawanan konvektif tebal di sekelilingnya (dinding mata). Kecuali jika siklon tropis berada di wilayah yang sangat mendukung perkembangannya, tahap matang biasanya hanya bertahan selama kurang lebih 24 jam sebelum intensitasnya mulai melemah.

4. Tahap pelemahan

Pada tahap punah, pusat siklon yang hangat mulai menghilang, tekanan udara meningkat dan wilayah dengan kecepatan angin maksimum meluas dan melebar menjauh dari pusat siklon. Tahap ini dapat terjadi dengan cepat jika siklon tropis melintas di wilayah yang tidak mendukung bagi pertumbuhannya, seperti misalnya memasuki wilayah perairan lintang tinggi dengan suhu muka laut yang dingin atau masuk ke daratan. Dari citra satelit dapat terlihat jelas bahwa wilayah konvektif siklon tropis tersebut berkurang, dan sabuk perawanan perlahan menghilang.

Siklon tropis memerlukan waktu 7 hari dalam proses pembentuannya, mulai dari tumbuh hingga punah. Akan tetapi variasinya bisa mencapai 1 hingga 30 hari. Indonesia bukan merupakan daerah pembentuk siklon tropis. Karena letak geografis Indonesia yang terletak di equator sehingga dipengaruhi oleh gaya coriolis. Kebanyakan siklon tropis terbentuk di daerah antara $10^{\circ}$ dan $20^{\circ}$ dari ekuator. Sehingga siklon tropis hanya terjadi di 
wilayah selatan Indonesia (Samudera Hindia) dan di wilayah utara Indonesia (laut cina selatan dan pasifik barat).

Siklon Tropis dapat berpengaruh terhadap pembentukan awan konvektif di daerah sekitarnya. Sehingga di daerah sekitar Siklon tropis lebih banyak mendapatkan Curah hujan. Hal ini akan mengganggu ke adaan cuaca di daerah yang tidak di lalui oleh shear. Tulisan ini akan membahas tentang pengaruh siklon tropis yang terjadi di Perairan selatan Indonesia pada tanggal 21 - 25 Maret 2014 terutama terhadap daerah Riau yang pada saat itu sedang dilakukan Teknologi Modifikasi Cuaca mengurangi kabut asap.

\section{METODELOGI}

Dalam pembahasan paper ini, digunakan metodologi sebagai berikut;

1. Pengumpulan Data

Data yang digunakan terdiri dari data primer dan data sekunder. Data primer yang dibutuhkan adalah data pengukuran curah hujan di suatu tempat. Data ini diambil dengan menggunakan penakar curah hujan sederhana atau manual maupun penakar otomatis. Data Sekunder yang dibutuhkan dalam pembahasan paper ini adalah, data-data yang berhubungan dengan kondisi atmosfer seperti; data Sea Surface Temperature (SST), Indian Ocean Dipole (IOD), El Nino Southern Oscilation (ENSO), Madden Julian Oscillation (MJO), dan Inter Tropical Convergence Zone (ITCZ). Selain itu diperlukan data gradient wind dan curah hujan spasial di wilayah Riau dan sekitarnya.

\section{Pembahasan dan analisa Data}

Data-data yang telah terkumpul dianalisa hubungannya terhadap curah hujan di wilayah Riau dan sekitarnya selama terjadinya Siklon Gillian.

\section{HASIL DAN PEMBAHASAN}

\subsection{Kondisi Cuaca Daerah Riau}

Riau merupakan daerah yang terletak antara $01^{\circ} 05^{\prime} 00^{\prime \prime}$ Lintang Selatan - 02 $2^{\circ} 5^{\prime} 00^{\prime \prime}$ Lintang Utara atau antara $100^{\circ} 00^{\prime} 00^{\prime \prime}-105^{\circ} 05^{\prime}$ 00" Bujur Timur dan membentang dari lereng Bukit Barisan sampai dengan Selat Malaka. Kondisi cuaca global/regional saat terjadinya Siklon Gillian dapat kita bahas sebagai berikut; 1. Indian Ocean Dipole (IOD)

IOD atau yang dikenal dengan sebutan Indian Ocean Dipole merupakan fenomena atmosfer di samudera hindia. Hal ini terjadi dikarenakan adanya anomali mendinginnya SST di Tenggara ekuator Samudera Hindia dan anomali menghangatnya SST di Barat ekuator Samudera Hindia. Saat terjadi anomali pendinginan SST di Tenggara ekuator Samudera Hindia, massa udara di Indonesai akan banyak tertarik ke Barat (Afrika Timur) yang mengakibatkan di daerah Afrika Bagian Timur mengalami hujan deras, sedangkan di Indonesia akan terjadi musim kemarau hebat dan kebakaran hutan. Fenemona ini dikenal dengan sebutan IOD Positif. Akan tetapi jika terjadi anomali menghangatnya SST di Barat ekuator Samudera Hindia, maka massa udara dari Barat (Afrika Timur) akan tertarik ke Indonesia yang mengakibatkan terjadinya hujan cukup tinggi di Indonesia. Fenomena seperti ini dikenal dengan IOD Negatif.

Pada bulan Maret 2014 Dipole Mode di Samudera Hindia (IOD) berada pada kisaran netral $\left(-0,1^{\circ} \mathrm{C}\right.$ s.d $\left.-0,6^{\circ} \mathrm{C}\right)$. Dimana pada akhir Maret 2014 nilai IOD bernilai $-0.6{ }^{\circ} \mathrm{C}$. Sehingga bisa diketahui bahwa selama bulan Maret 2014 , indeks IOD cukup signifikan dalam menambah peluang peluang pertumbuhan awan di wilayah Indonesia bagian barat. Berikut data indeks IOD yang diambil dari sumber www.bom.gov.au.

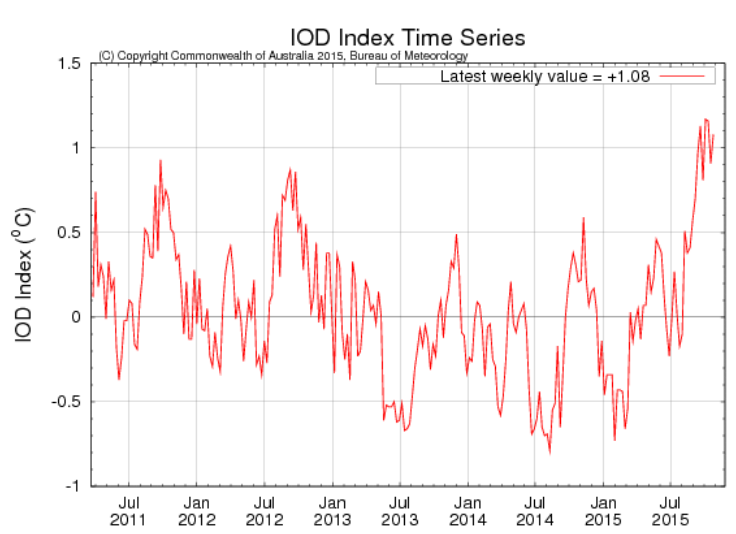

Gambar 1. Indeks IOD

\section{El-Nino dan La-Nina}

ENSO atau yang dikenal dengan sebutan EI Nino Southern Oscilation merupakan fenomena alam yang muncul di sekitar Samudera Pasifik yang mempengaruhi kondisi cuaca di sekitarnya. El Nino disebabkan karena meningkatnya suhu permukaan laut di pasifik equator tengah (di atas normal) yang biasanya diikuti penurunan suhu permukaan laut di perairan Indonesia (di bawah normal). Hal ini dapat menyebabkan massa uap air dari perairan Indinesaia terbawa ke perairan Samudera Pasifik equator tengah, sehingga curah hujan di sebagian besar wilayah Indonesia berkurang. Akan tetapi kondisi El-nino yang cukup kuat tidak akan memberikan pengaruh yang signifikan jika suhu permukaan laut di perairan Indinesia juga menghangat. Sedangkan La-Nina merupakan fenomena alam yang ditandai dengan mendinginnya suhu permukaan laut di pasifik equator tengah. La-Nina biasanya ditandai dengan kembali normalnya suhu 
permukaan laut di perairan Pasifik equator tengah setelah mengalami El-Nino kuat.

Pada bulan Maret 2014 indeks ENSO masih masuk kategori normal. Dimana indeks ENSO terlihat dari grafik dibawah masih berada pada kisaran $-0.2 \mathrm{~s} / \mathrm{d} \quad-0.4$ mengindikasikan bahwa pada bulan maret baik El-Nino maupun La-Nina tidak mempengaruhi kondisi cuaca di daerah Riau pada bulan Maret 2014. Berikut grafik ENSO dari sumber www.bom.gov.au

Fenomena MJO (Madden Julian Oscillation) merupakan suatu fenomena yang

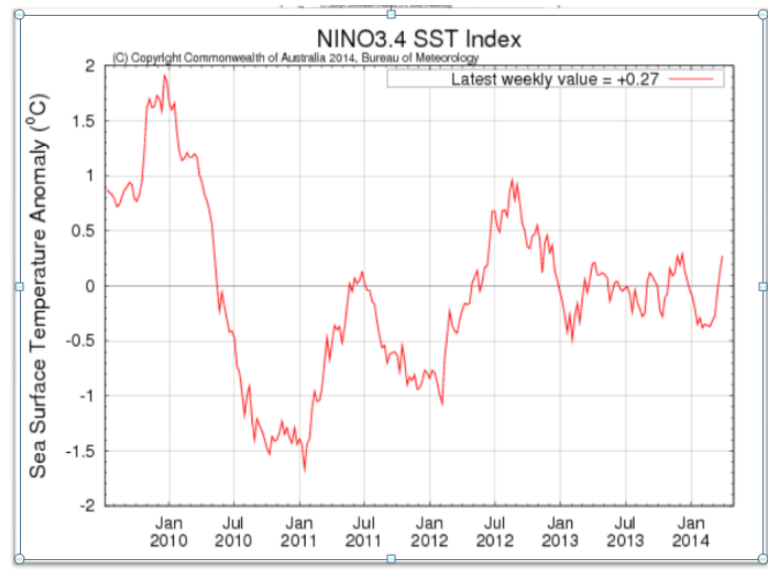

Gambar 2.Indeks El-NINO

\subsection{Hasil Curah Hujan Data Penakar BMKG}

Penakar BMKG dipasang menyebar di wilayah provinsi Riau. Ada 13 Penakar yang digunakan sebagai data penunjang kegiatan penambahan Curah hujan dalam menangani bencana Kebakaran Lahan dan Hutan di Provinsi Riau. Berikut latitude dan longitude setiap penakar yang ada berdasarkan data dari posko meteorologi BMKG:

Tabel 1. Lokasi Pos Meteorologi Pekanbaru

\begin{tabular}{|c|l|r|r|}
\hline No & \multicolumn{1}{|c|}{ Stasiun } & \multicolumn{1}{c|}{ Lat } & \multicolumn{1}{c|}{ Lon } \\
\hline 1 & Pekanbaru & 0.461 & 101.44 \\
\hline 2 & Dumai & 1.667 & 101.45 \\
\hline 3 & Pelalawan & 0.151 & 102.55 \\
\hline 4 & Taluk Kuantan (Kuantan Singingi) & 0.501 & 101.54 \\
\hline 5 & Bengkalis & 1.499 & 102.14 \\
\hline 6 & (Rokan Hilir) & 1.572 & 101 \\
\hline 7 & Pasir Pengaraian (Rokan Hulu) & 0.896 & 101.3 \\
\hline 8 & Siak & 1.197 & 102.18 \\
\hline 9 & Bangkinang (Kampar) & 0.323 & 101.01 \\
\hline 10 & Tiga Belas Koto Kampar (Koto Panj & 0.317 & 100.73 \\
\hline 11 & POSMET Rengat & 0.375 & 102.545 \\
\hline 12 & POSMET Dumai & 1.684 & 101.447 \\
\hline 13 & POSMET Pelalawan & 0.423 & 101.85 \\
\hline
\end{tabular}

berpengaruh terhadap pola aktivitas awan konvektif dan pola curah hujan. MJO mempunyai waktu siklus 30-60 hari. Sehingga dapat membantu memprakirakan cuaca 2-3 minggu ke depan. MJO pada bulan Maret berada pada fase 6 hingga 2 dengan sifat lemah hingga kuat, dimana MJO tidak melewati Indonesia (fase 3 dan 4) sehingga pada bulan Maret MJO tidak berpengaruh terhadap penambahan atau pengurangan curah hujan di wilayah Indonesia (BMKG,2014). Perhatikan gambar Fase MJO.

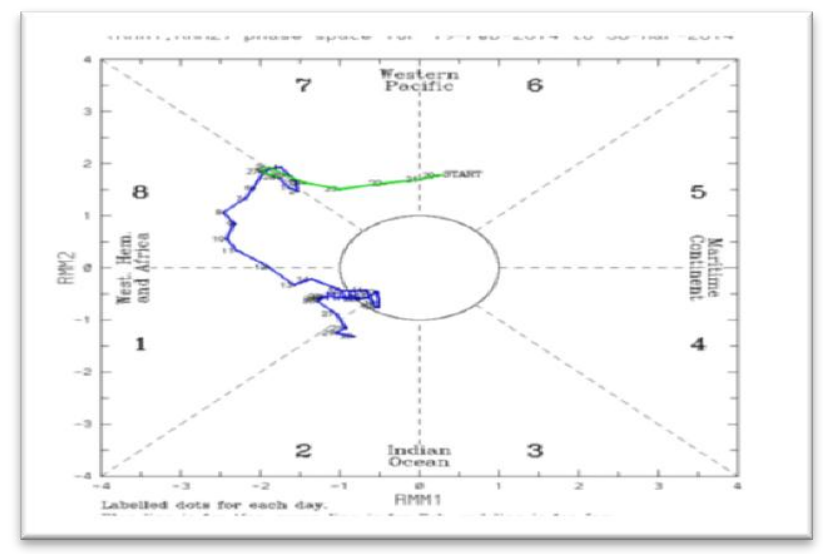

Gambar 3. Fase MJO

Untuk menganalisis pengaruh siklon tropis Gillian terhadap wilayah Riau, maka digunakan data Curah Hujan dari 13 penakar BMKG yang tertera pada table di atas.

Dimana data yang digunakan sebagai perbandingan dibagi menjadi tiga, yaitu data Curah Hujan Sebelum Siklon Tropis (16-20 Maret 2014), data Curah Hujan Selama Siklon Tropis (21-25 Maret 2014), dan data Curah Hujan Setelah Siklon Tropis (26-30 Maret 2014). Berikut data Curah hujan dari ke-13 penakar yang disajikan dalam bentuk grafik.

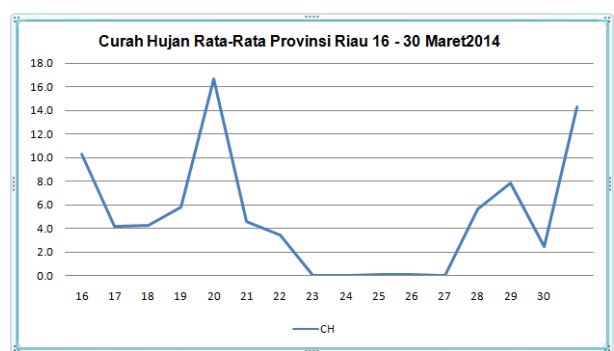

Gambar 4. Curah hujan Provinsi Riau (16-30 Maret 2014) Source: Penakar BMKG 2014 


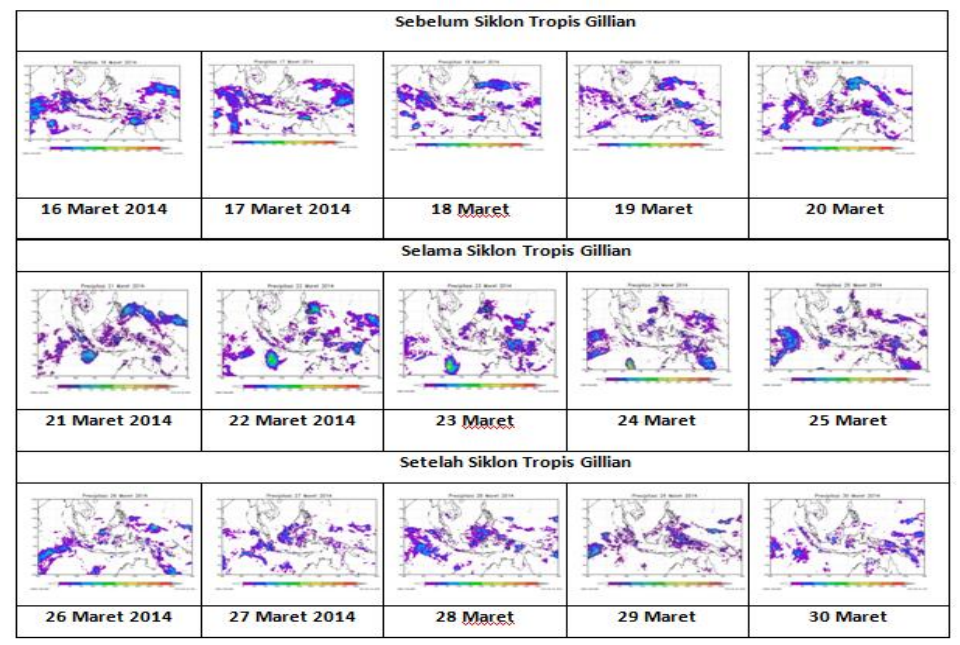

Gambar 5. Distribusi Curah hujan Provinsi Riau (16-30 Maret 2014) Source:TRMM-Jaxa

Dari data di atas terlihat adanya penurunan curah hujan dari tanggal 21-27 Maret 2014. Bahkan dari tanggal 23-27 Maret Curah hujan di wilayah Provinsi Riau mendekati 0 . Ini berarti hampir tidak ada hujan di daerah tersebut. Curah hujan kembali

\subsection{Gradient Level Wind Analysis}

Gradient level wind memperlihatkan kondisi angin pada level $900 \mathrm{mb}$ atau $1000 \mathrm{~m}$. Dari gradient level wind yang bersumber dari bom.gov.au dapat diketahui arah angin, kecepatan angin dan tekanan atmosfer baik tekanan rendah maupun tekanan tinggi, arus Eddy dan Siklon Tropis. Gradient level wind tanggal 21 - 25 Maret 2014, terlihat adanya siklon tropis di perairan selatan Pulau Jawa. Siklon menggalami peningkatan pada tanggal 28-31 Maret 2014.

tropis tersebut mempengaruhi keadaan curah hujan di daerah sekitar terjadinya siklon bahkan di daerah Riau dan sekitarnya. Dimana pada tanggal tersebut daerah Riau sedang menerapkan Teknologi Modifikasi Cuaca mengurangi kabut asap. Data gradient level wind saat terjadinya siklon tropis terlihat pada gambar di bawah ini:

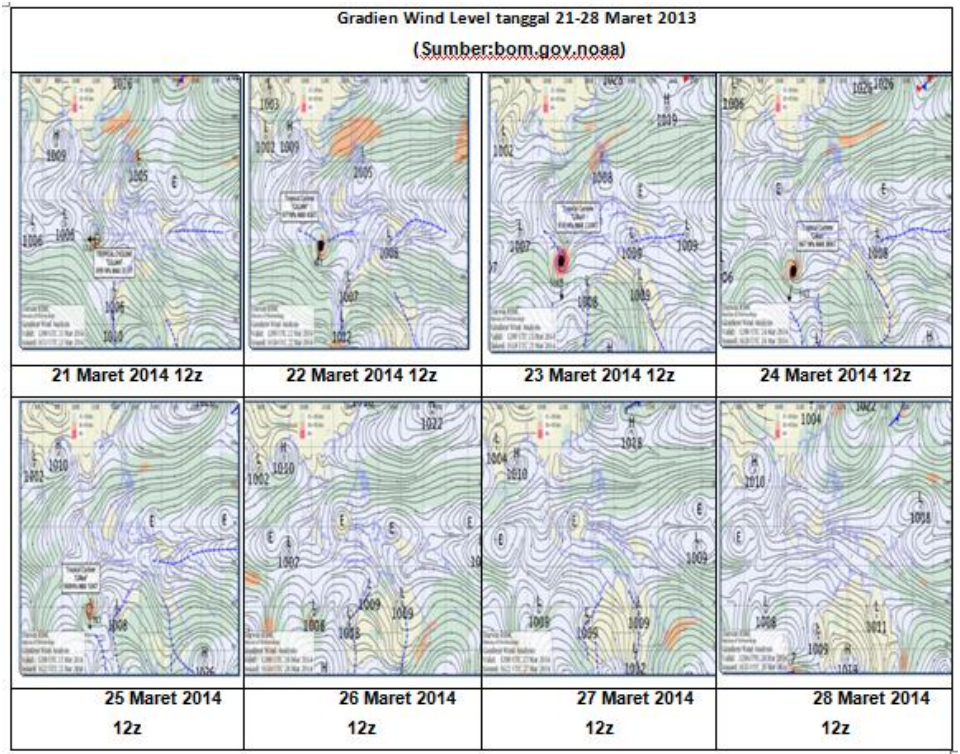

Gambar 6. Gradien Wind Level tanggal 21-28 Maret 2013 Source: http://www.bom.gov.au

\section{PEMBAHASAN}

Seperti yang telah kita bahas sebelumnya, keadaan atmosfer di daerah provinsi Riau pada bulan Maret masih dalam keadaan normal. Belum ada pengaruh ENSO, MJO, IOD dan fenomena atmosfer lainnya. Akan tetapi pada akhir bulan Maret, terjadi Siklon Tropis di bagian Perairan selatan Indonesia, Sehingga mempengaruhi Curah Hujan di daerah tersebut.

Berdasarkan display TRMM Jaxa, Akibat Siklon Tropis Gillian, pada tanggal 15 - 
25 Maret 2014, massa udara tertarik ke Perairan selatan Indonesia. Hal ini mengakibatkan Keadaan Atmosfer Sumatera kering.

Pengaruh Siklon Tropis terhadap kondisi atmosfer di Pulau Sumatera terlihat pada daerah Pekanbaru. Berdasarkan data analisa curah hujan, dari TRMM dan data real penakar BMKG, daerah Riau mengalami penurunan curah hujan pada tanggal tersebut.

Berdasarkan data curah hujan dari BMKG dan penakar POSMET, sebelum terbentuknya Siklon tropis (16-20 Maret 2014) dan setelah siklon tropis (26-30 Maret 2014) di perairan selatan Indonesia, daerah Riau menerima curah hujan dengan intensitas cukup tinggi, jika dibandingkan dengan curah hujan selama terjadinya siklon tropis di selatan Indonesia (21-25 Maret 2014).
Dari grafik perbandingan data $\mathrm{CH}$ TRMM dan $\mathrm{CH}$ Penakar BMKG, terlihat adanya penurunan $\mathrm{CH}$ pada tanggal 21 - 22 Maret 2014, dan akhirnya pada tanggal 23-24 Maret 2014 curah hujan di daerah Riau $0 \mathrm{~mm}$. Ada penyimpangan data Curah hujan pada tanggal 26-27 Maret 2014. Tanggal tersebut merupakan kondisi dimana Siklon Tropis Gillian telah hilang. Akan tetapi nilai $0 \mathrm{~mm}$ pada tanggal tersebut menandakan keadaan atmosfer di daerah Riau masih cukup kering dan belum mendukung terbentuknya awan-awan konvekti. Jika kita amati gradient level wind pada tanggal 26-27 Maret 2014, terlihat wilayah Riau bukan merupakan wilayah konvergensi, karena adanya pengaruh Eddy di sebelah Barat dan timur Pulau Sumatera.

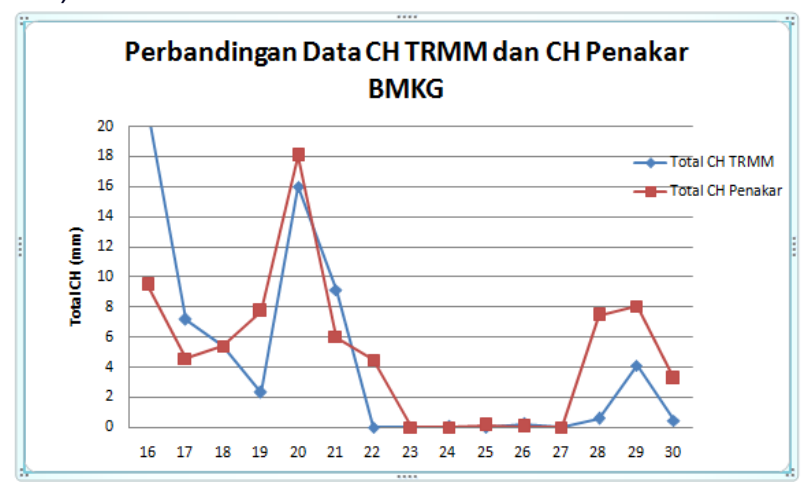

Gambar 7. Grafik Perbandingan Curah hujan Provinsi Riau (16-30 Maret 2014) Source: Penakar BMKG 2014 dan TRMM Jaxa

\section{KESIMPULAN}

Siklon Tropis dapat mempengaruhi keadaan atmosfer di sekitar terjadinya. Terlihat Siklon Tropis Gillian yang terjadi di perairan Selatan Indonesia mempengaruhi terjadinya Curah Hujan di daerah tersebut. Daerah Riau menjadi salah satu daerah yang menerima pengaruh dari Siklon Tropis Gillian. Terjadi penurunan Curah hujan bahkan hingga $0 \mathrm{~mm}$ selama terjadinya Siklon Tropis.

\section{REFERENSI}

Ropelewski, C.F. dan Halpert, M.S.. 1987. Global and Regional Scale Precipitation Patterns Associated with the El Nino/ Southern Oscillation. Monthly Weather Review. 115. 1606 â€“ 1626.

Trenberth, K. E dan J. M. Caron. 2000. The Southern Oscillation Revisited: Sea Level Pressures, Surface Temperatures and Precipitation. Journal of Climate. 13. 4358 â€“" 4365.

Trenberth, K.E dan David P. Stephaniak. 2001. Indices of El NiÃ \pm 0 Evolution. Journal of Climate. 14. 1967 â€“" 1701.

Aldrian, E. 2008. Meteorologi Laut Indonesia. Jakarta : Badan Meteorologi dan Geofisika.

Trenberth, K.E. 1997. The Definition EI Nino. Bulletin of the American Meteorological Society. Volume 78. No 12. 2771-2777.

http://moklim.bdg.lapan.go.id/content/enso-elnino-southern-oscillation

http://meteo.bmkg.go.id/siklon/learn/06/id 
